Article

\title{
Immigrant Children and the Internet in Spain: Uses, Opportunities, and Risks
}

\author{
Miguel Ángel Casado ${ }^{1, *}$, Carmelo Garitaonandia ${ }^{2}$, Gorka Moreno ${ }^{3}$ and Estefanía Jiménez ${ }^{1}$ \\ ${ }^{1}$ Department of Audiovisual Communication and Advertising, University of the Basque Country, 48940 Leioa, Spain; \\ E-Mails: miguelangel.casado@ehu.eus (M.Á.C.), estefania.jimenez@ehu.eus (E.J.) \\ ${ }^{2}$ Department of Journalism, University of the Basque Country, 48940 Leioa, Spain; E-Mail: carmelo.garitaonandia@ehu.eus \\ ${ }^{3}$ Department of Sociology and Social Work, University of the Basque Country, 48940 Leioa, Spain; \\ E-Mail: gorka.moreno@ehu.eus \\ * Corresponding author
}

Submitted: 15 March 2018 | Accepted: 7 September 2018 | Published: 5 February 2019

\begin{abstract}
This article describes the use made of the Internet by immigrant children living in Spain and the opportunities and risks it involves. Specifically, it deals with children from the Maghreb, Ecuador, and Sub-Saharan Africa, three regions which account for a quarter of Spain's foreign-born population. A qualitative methodology was used, based on in-depth interviews with 52 children from these countries and educators from their support centres. Immigrant minors usually access the Internet via their smartphones rather than via computers. They have a very high rate of smartphone use and access the Internet over public Wi-Fi networks. However, they make little use of computers and tablets, the devices most closely associated with education and accessing information. Internet usage is fairly similar among immigrant and Spanish teens, although the former receive more support and mediation from their schools and institutions than from their parents. The Internet helps them to communicate with their families in their countries of origin. As one educator puts it, "they have gone from sending photos in letters to speaking to their families every day on Skype". Some teens, particularly Maghrebis, sometimes suffer from hate messages on social networks.
\end{abstract}

\section{Keywords}

children; cyber-bullying; immigrant; Internet; media risks; Spain; youth

Issue

This article is part of the issue "Communicating on/with Minorities", edited by Leen d'Haenens and Willem Joris (KU Leuven, Belgium).

(C) 2019 by the authors; licensee Cogitatio (Lisbon, Portugal). This article is licensed under a Creative Commons Attribution 4.0 International License (CC BY).

\section{Introduction}

The use of personal communication technologies is becoming ever more commonplace among minors. In Spain, children as young as seven are now beginning to use mobile phones (Garmendia, Jiménez, Casado, Garitaonandia, \& Mascheroni, 2017). Mobile devices (smartphones and tablets) provide opportunities for communicating with family and friends, socialising, learning and performing schoolwork, accessing information, being creative, and in general for leisure and entertainment (Goggin, 2010; Goggin \& Hjorth, 2014; Hjorth \&
Goggin, 2009). Even aside from these benefits, however, the Internet has become a tool they can use to exercise their rights. Although Internet access is not in itself a right, it has become a basic tool for exercising such rights, given that children relate to the world over the Internet (Third, Bellerose, Dawkins, Keltie, \& Pihl, 2014).

Nonetheless, despite improvements in Internet access, many children are still unable to go online or can only do so in a very limited way. Such situations are to a great extent related to their families' socio-economic status and the resources they can spend on Internet access (Livingstone, Haddon, Görzig, \& Ólafsson, 2011; 
Mascheroni \& Ólafsson, 2014). In other cases, although they do have access to the Internet, the potential advantages of its use are restricted by their families' educational limitations (Garmendia, Garitaonandia, Martínez, \& Casado, 2012). As Salemink (2016, p. 1170) has remarked, this has led to a situation in which: "Research on digital inclusion increasingly focuses on vulnerable groups, with the prevailing idea that social exclusion leads to digital exclusion".

This article sets out to analyse the relationship of vulnerable children with the Internet. Within this group, the article centres specifically on the situation of minors from immigrant families in Spain. There are two reasons for this focus. On the one hand, internationally, members of the immigrant community suffer much higher rates of inequality and exclusion than the social average (Borjas, 1985; Massey \& Eggers, 1990; Portes, 1995); in the specific case of Spain, this situation has been further aggravated by the economic crisis (Godenau, Rinken, Martínez de Lizarrondo, \& Moreno, 2014; Mahía $\&$ de Arce, 2014). Secondly, immigrant families might display different or more intense use of social media and communication tools in order to maintain contact with their home countries (Buckingham \& de Block, 2005; De Leeuw \& Rydin, 2007).

The article is divided into four sections: an initial review of the research on minors in situations of inequality and the Internet and the context of migrant children in Spain; a second section setting out the objectives and methodology of this study; a third section describing the main findings of the field work and, finally, our conclusions.

\section{Theoretical and Contextual Framework}

\subsection{From Digital Divide to Digital Inequality}

The term "digital divide" was coined in the early years of the Internet, when it was associated with varying rates of access to communication technologies among different regions (Bindé, 2005; DiMaggio \& Hargittai, 2001; Norris, 2001; Van Dijk, 2005). Although still an issue in terms of the major differences in access ${ }^{1}$ between certain countries, the concept has evolved with the spread of communication technology, and today there is more talk of digital inequality than of digital divide, since digital inequality is not a simple dichotomy of 'access' versus 'no access'.

In the adoption of communication technologies, there are two opposing points of view. The hypothesis of standardization asserts that communication technologies have the capacity to reduce social inequalities. The hypothesis of stratification, on the other hand, indicates that this process of the adoption of communication technologies ends up reinforcing existing inequalities (Mesch, 2012). In this context, there are many studies which point to the difficulties the lower classes have in accessing and using digital devices.

Katz, Gonzalez and Clark (2017) have shown that although over $90 \%$ of economically underprivileged families had Internet access, most complained that they were unable to make full use of the Internet because of low speeds, the need to share devices or the existence of just one mobile connection, resulting in data overload (Katz et al., 2017). As Robinson (2009, p. 489) remarked, it is necessary to examine "how digital inequality is related to larger social inequalities".

Digital inequality also has very important implications for the personal development of children and teens, their relationship with family and friends, their education, and their upbringing. Children who use the Internet at home and school have a higher level of "self-efficacy" than those who do not, and such online efficacy is associated with better school results (Jackson, Eye, \& Biocca, 2003; Katz et al., 2017). Clark (2005) has shown that providing digital technologies to young people from minorities and those in precarious economic situations can increase their skills (i.e., their self-efficacy) in areas such as mathematics and science.

In addition to the reduced opportunities, these minors are more vulnerable to online risks. Although they may be exposed to similar levels of risk, such hazards may be more damaging to them (Paus-Hasebrink, Ponte, Dürager, \& Bauwens, 2012, p. 267). At the same time, families from low socio-economic backgrounds tend to have more restrictive parental mediation styles, which can also result in fewer opportunities for the child (Garmendia et al., 2012). This lack of opportunity must be looked at from a broad perspective, not only considering information and communication technologies as tools for academic development but also as tools that allow minors to participate in social life in many ways and to have access to a multitude of content that can be potentially positive for them (Livingstone \& Helsper, 2010).

A number of recent studies have shown that in many countries there are still major differences in access highlighting the importance of the rural-urban variable in these differences. In Taiwan, Wang (2013) notes that these differences impact urban schoolchildren's experience and preferences in the use of digital technologies for learning. Venkataswamya and Vidyapeetham (2015) show that in India, ownership of such devices has created new hierarchies of inequality; iPads and other tablets are associated with status and prestige. An extreme case is China (Yang et al., 2013), where $80 \%$ of urban students have a computer and $73 \%$ have Internet access, as compared to just $6 \%$ and $2 \%$ respectively among students from minority groups. In Brazil, $98 \%$ of minors aged between nine and 17 years from higher socio-economic groups had connected to the Internet in the previous three months, as opposed to $23 \%$ from lower socioeconomic backgrounds (TIC Kids Online Brasil, 2017).

\footnotetext{
${ }^{1}$ While $88.1 \%$ of North Americans and $77.4 \%$ of Europeans are Internet users (as of 2017 ), in Africa and Asia the figure is only $28.3 \%$ and $45.2 \%$ respectively. See more at www.exitoexportador.com/stats.htm
} 
In Europe, where Internet use among children is broader, some research has focused on children in vulnerable situations due to their families' economic situation. As Paus-Hasebrink, Sinner and Prochazka (2014, p. 8) note:

The educational background of the family (which correlates highly with the economic well-being of a family) plays the major role influencing the different ways the internet is used. Children of lower educated parents are often left alone when dealing with the internet.

Several studies have explored differences in the development of digital skills between minors from underprivileged contexts and others. In Italy, levels of digital literacy were found to be greater among children from more privileged socio-economic backgrounds (Gui, 2007). In the Netherlands, no major differences were detected in the use of technologies among young people from different socio-economic environments. However, there were differences in the activities they pursued: children from higher socio-economic backgrounds spent more time searching for information and less on entertainment than those from lower-income backgrounds (Peter \& Valkenburg, 2006). Other studies have also shown the importance of intervention policies designed to provide underprivileged children with access and equipment. A study in Portugal by Simões, Ponte and Jorge (2013) has shown only a small-skills gap between underprivileged children supported by a household equipment programme (Escolhas) and other children. In Spain, a qualitative study by Cabello (2013) has shown that associations and institutions that facilitate access to communication technologies among such children play an important role in raising their awareness of online risks.

In addition to the socio-economic aspects, different studies have also pointed out the importance of taking into consideration ethnic origin in the use that is made of the Internet. Thus, for example, the works of Mesch (2012) point to the different objectives that different communities can have when using the Internet and the possibilities of Internet communication to overcome social barriers and segregation (social diversification hypothesis).

Within the general context of underprivileged children, some studies have focused more specifically on immigrant families.

D'Haenens and Ogan (2013) made a comparative study of Internet usage among European children of Turkish origin in various EU countries (Austria, Bulgaria, Denmark, Germany and the Netherlands), autochthonous children in those countries and Turkish children living in Turkey. The children from the Turkish diaspora stood in an intermediate position between their native European counterparts - the most assiduous Internet browsers-and Turkish children living in Turkey, who use the Internet least. In general terms, the same is true for online skills and activities. As for exposure to online risks, the native European children send and receive images and messages related to sex and have more face-toface encounters with online contacts than the other two groups. On the other hand, children from the Turkish diaspora suffered from cyber-bullying more frequently.

Among immigrant households, especially secondgeneration members, children can play an important role in helping their parents with digital technologies. In Dutch-Moroccan families, girls know more about digital technologies and their use than their parents and are able to help them stay in touch with relatives at home; this knowledge can also help the girls create a space of their own, unmonitored by their parents. The use of digital technology by girls helps to create lines of connection and support for their grandmothers, mothers, aunts, and sisters (Leurs \& Ponzanesi, 2013).

Also in Denmark, results of the Danish survey clearly indicate that ethnic minority youth are more active than the youth of Danish descent in practising key aspects of media and information literacies (Drotner \& Kobbernagel, 2014, p 15).

Some immigrant ethnic minorities in Europe, such as Asian Muslims, retain lower social and economic levels (Abbas, 2008) and are hampered by having relatively less access to ICT (Khan \& Ghadially, 2010). These inequalities may be further accentuated by their schools. Islamic faith schools, in particular, sometimes reinforce the restrictions (on access to social media, messaging apps, posting of videos on Youtube or Facebook, access to common areas, etc.), rather than compensating for such shortfalls (Hardaker, Sabki \& Iqbal, 2017).

Regarding the risks, Strohmeier, Kärnä and Salmivalli (2011, p. 255) examined first- and second-generation immigrants in Finland (who are less numerous than in other European countries and mainly of Caucasian origin), finding that "both first- and second-generation immigrants were more often victimized by peers compared with native youth. Thus, we can conclude that immigrant youth are at higher risk of being victimized by their peers in Finland".

\subsection{Migrant Children in Spain}

Spain has 4.6 million foreign-born residents, who make up $10 \%$ of the total population (INE, 2016). Immigrants suffer higher levels of social vulnerability and precariousness than the local population (IOÉ, 2012). From the outset, the recession hit the foreign population particularly hard, with the incidence of exclusion amongst these households doubling to $44.5 \%$ in 2009 . Since then, the situation has continued to deteriorate, with a significant increase in the rate of severe exclusion among this group (22.4\%) and a rise in the index of exclusion to 2.76 (Foessa, 2014, p.30). In educational terms, a recent joint study by UNICEF Spain and the Autonomous University of Barcelona also shows that being from a migrant background is one of the most significant factors contributing 
to educational exclusion (UNICEF, 2017). The findings of the PISA report also show that migrant pupils have worse grades (Calero \& Escardíbul, 2016).

The three immigrant groups covered by the studyMaghrebis, Ecuadorean, and Sub-Saharans-account for nearly a quarter (24.8\%) of Spain's foreign-born population. Rates of labour and social vulnerability and precariousness are highest among Maghrebis (the largest group, accounting for $14.2 \%$ of foreign nationals (INE, 2017) and Sub-Saharans (Domingo \& Sabater, 2013; IOÉ, 2012b; Izquierdo, 2011; Mullor, 2011). These groups (especially Maghrebis) also suffer from a higher degree of rejection by the local population (Cea D'Ancona, 2016; Ikuspegi, 2017; Rinken, 2015). Young people of Maghrebi origin have the lowest Internet usage levels $(46.6 \%$ compared to $55.1 \%$ among immigrants as a whole). However, this does not appear to be due to their lack of interest, rather than the greater difficulties they experience in accessing the Internet: FUNDACC figures show that this group uses the greatest variety of connection locations (in order of frequency: home, call shop, or cyber cafe, workplace and school; Huertas, Martínez, \& Moreras, 2013).

Ecuadoreans tend to have spent a considerable time living in Spain and as native Spanish-speakers, have fewer difficulties with integration. The children have often been born in Spain or have at least spent much of their lives living there. Most have Spanish nationality or long-term residency permits, a key factor in social integration (Martínez de Lizarrondo, 2016). However, they also suffer high unemployment and low levels of income (Iglesias et al., 2015). Nonetheless, as Lara (2014, p. 546) points out, in Spain, "it is remarkable that, despite the difficulties associated with the immigration process, immigrants showed equal levels of life satisfaction as natives". Among other causes, she attributes it to the fact "that immigrants show better adaptation despite their poorer economic status" (Lara, 2014, p. 546).

In any case:

Foreign nationals do not renounce their identities constructed before their arrival in Spain, and in this sense, the media are one of the links that allow them to keep these identities alive; it is the strongest sociocultural link uniting them with their country of origin. (Lobera, Arco, \& Giménez, 2017, p. 47)

\section{Purpose and Methodology}

The aim of this article is to analyse the relationship that children from immigrant backgrounds and in situations of economic vulnerability have with communication technologies. We shall essentially consider two aspects. On one hand, we shall examine access by these minors to new communication technologies, looking at the devices they use, the way they use them, and the activities they perform. On the other hand, we shall assess their exposure to online risks, considering their perception of the risks and their capacity to cope with them.
These three aspects are considered in the light of the possible influence of the children's socio-economic background and origin.

The research is qualitative, based on in-depth interviews using a semi-structured conversation guide. A total of 52 children of different origins resident in Spain were interviewed. 30 were of Maghrebi origin, 11 Ecuadorean, and 11 Sub-Saharan. The children interviewed were between the ages of 10 and 17. Most interviews were individual, except for a small number in which two people participated simultaneously. In the first case, the duration of the interviews was almost always between 30 and 40 minutes. The interviews in which two children participated lasted about an hour. As explained below, the groups were selected to reflect their representation among the immigrant community in Spain. In order to take into account the variable of socio-economic vulnerability, minors were contacted through collaboration with a number of organizations running projects providing support to children at risk of socio-economic exclusion. All the children in the sample were in situations of exclusion or risk of exclusion, in most cases due to their family's lack of financial resources. The families of these children came to the centres mentioned in this study in search of economic and educational support. The interviews were conducted on the premises of these collaborating associations and were based on a semi-structured questionnaire that included issues related to access, use, risks, opportunities and mediation received in the use of the internet. Permission to conduct all interviews was received from the minors' families or guardian institutions. To try to provide a greater variety of cases and situations, the interviews were conducted in six Spanish provinces: Madrid, the Canary Islands, Barcelona, Seville, Valencia, and Biscay. The interviews were conducted in the capitals of the four Autonomous Communities with the largest populations in Spain (Andalusia, 8.4 million inhabitants; Catalonia, 7.5 million; Madrid, 6.5 million and the Valencian Community, 5 million), and in addition in the Basque Country and in the Canary Islands, both of which have a combined population of 2.1 million.

As well as the children themselves, a further five interviews were held with educators from the centres attended by some of the minors, to obtain another opinion regarding their relationship with communication technologies.

\section{Migrant Children in Spain}

\subsection{Access and Usage}

Generally speaking, children from these immigrant groups often have mobile phones and use them to access the Internet. This device has become a basic tool for them. Indeed, educators from the schools agreed that it has become an essential device, even in the case of families in extreme economic situations: 
Their parents might not have money for food or upkeep, but they still come in with a mobile. They get presents of the sort of tablet even I wouldn't have, even when they can't afford to cover their basic living needs like food, clothes and so on. (Director of a centre for minors)

Some have data packages on their phones or Wi-Fi at home, but frequently need to resort to using Wi-Fi at their friends' or relatives' homes or in public places. However, it is less common for them to have a computer at home. Many children only have access to computers in the classroom and in support centres. Some said they did their schoolwork directly on their mobiles:

It's no problem, you don't need a computer. For example, when I have an assignment, I can do it on my mobile. (Boy, 15, Maghreb)

The principal activities mentioned were viewing videos and listening to music on Youtube and Musical.ly; using WhatsApp and social media (particularly Instagram and, to a lesser extent, Facebook). The use of these platforms matches the general trends among children in Spain (Garmendia et al., 2017). Where children have such devices and an Internet connection, they also use them for activities that are useful for their personal development and education:

I keep a blog and I make videos of handicrafts. For example, I did a handicrafts video for Mother's Day and another for Father's Day, to show people how to make presents for their father and their mother. I do handicrafts, mandalas, things like that. (Girl, 11, Ecuador)

What is different in the case of migrant children is that as well as communicating with family and friends, social media offer them the possibility of keeping in touch relatively simply with their countries of origin.

Instagram is more for your circle of friends. I have relatives on Instagram too, but mostly I use it for my friends. With Facebook, it's the opposite. I use it more for my family. Because my father's family is in Ecuador, I use Facebook to communicate with them and to keep up with what's going on. (Girl, 16, Ecuador)

I normally use Facebook and Instagram to talk to my friends in Morocco and here, but more with my friends in Morocco. (Boy, 10, Maghreb)

In the particular case of unaccompanied minors being looked after in specific programmes or centres, regular everyday access to ICT is even more important. The director of one such centre described how the situation of such children has changed in a very short space of time, saying that they have gone from seeing "how their siblings were growing up through photographs sent in let- ters" to "having a daily relationship by video conference over Skype".

In general, children learn to use and master the applications from older friends and relatives, often cousins or siblings:

I began using social media because I saw that my cousins and relatives had it, so I started too. I've gradually learned how to use it....So, for example, I saw that my cousins had Instagram and they taught me how to use it. (Girl, 13, Ecuador)

In practically all cases-except for younger interviewees - the children said they knew more about these tools than their parents. Because of this lack of knowledge among parents, they tend to develop very restrictive mediation strategies:

I used to have another mobile, but it broke. It wasn't my fault. My mother dropped it and it broke. (Girl, 14, Maghreb)

Alternatively, some parents go to the other extreme, with no clear rules on the use of mobile phones. As the children themselves recognise, this results in excessive use. Among the most significant effects mentioned were extended night-time use of the phone in their bedrooms and subsequent loss of sleep time.

If I go home right now, I might be on the phone for an hour. Then l'd do something else and l'd be on my mobile again for half an hour or so. I might spend up to three hours per day on the mobile. (Boy, 16, Maghreb)

There's no one there when you go to bed, so you get distracted by the mobile. You might be on it for a few hours without realising. (Boy, 15, Sub-Sahara)

Sometimes I get less sleep because I'm on the mobile. That's true. And it'll be more now that the holidays are starting. (Girl, 16, Sub-Sahara)

Regular use of ICT helps children develop many communication skills, but not other digital skills that are essential for building a complete and competent digital personality. As users, they cope well with social media but they have not developed a mature criterion for finding basic information and services on the Internet.

These kids can do things that really freak me out. One guy hacked into my photos from his phone, which is something l'd never see anyone do in my life. Then another one hacked the Wi-Fi password. They know how to do loads of things. But when it comes to logging onto a website or looking for information on citizen services that are available to everyone, they don't know where to start. (Educator at children's support centre) 


\subsection{Perceived Risks}

As regards the hazards of Internet use, the risks most frequently mentioned by the children involve control of information; possible consequences of posting certain images; use of false profiles to obtain information or trick them; and the possibility that their accounts are being hacked into.

A: It happened recently to two friends of mine: someone hacked into their Instagram account and created another account with their photos.

B: That happens a lot on Instagram, they steal your account or create another new one, put another name on it and upload your photos and your information or whatever. Just to piss you off. (Girls, 17, Maghreb)

In this respect, the gender component is especially important, especially in the case of sexual images. In cases of "sextortion", the images can be used to humiliate or blackmail the victim. Such incidents occur with the same frequency among native Spanish children.

Yes, she was stupid. This guy told her he wanted to get to know her. She sent him a photo showing lots of cleavage and her schoolmates started teasing her about it. (Girl, 16, Maghreb)

I stopped answering him because he asked me for a quite explicit photo, you know? I stopped replying to him and he started calling me fat and things like that. I got pissed off and just ignored him. (Girl, 14, Maghreb)

I take explicit photos. Though of course, I don't show my face. I don't know most of the people personally, because they're not usually from the same country. (Girl, 14, Maghreb)

In terms of risks, the main difference mentioned compared to native children is their exposure to Internet hate speech. This is particularly true among children of Maghrebi origin. They find that in situations of conflict, their ethnic or migratory origin is often used against them.

Specifically on Instagram. They upload doctored photos and put phrases on them like "go home" or "fucking Arab [mora]". Those are normally the keywords. (Girl, 17, Maghreb)

You see it, especially on Instagram and Facebook. They're not people who actually promote these ideas, but they have this black humour, you know? And if it wasn't so hurtful, perhaps it would be funny. (Girl, 14, Maghreb)
At the same time, some children are upset when they find Internet contents linking Islam-which they identify with-to terrorism - which they don't. This is especially relevant because of the negative effect it has on the children's integration, given the impact these messages have on their host environment and on the way they themselves feel. The Internet has become another reflection of the Islamophobia detected throughout Spanish society (Cea D’Ancona, 2016).

All this business about terrorists and so on annoys me-the way people generalise; the way they consider all Muslims to be terrorists rather than just the Jihadists. (Boy, 16, Maghreb)

\section{Conclusions}

All children should have the right to Internet access. This right should be guaranteed, particularly for those who are excluded due to their country of origin, economic situation, or any other form of discrimination (religion, sex, ideology, disability, etc.). It should extend, not only to Internet access but also to ensuring that such access is safe and allows them to benefit from all online opportunities. In the specific case of immigrant children, the participation of minors on the Internet is particularly important. Involvement with and an active role in the digital environment can make the Internet a powerful tool to help overcome social barriers and to contribute to personal development. Moreover, the Internet can provide children with access to content and realities that they would be unable to access in the precarious environments in which they are growing up and also give them the opportunity to discover and develop new skills.

The penetration rate of smartphones and the uses that immigrant minors make of them are, to a large extent, very similar to those of Spanish minors. In this context, communication tools such as WhatsApp or Instagram take precedence over all others. This intensive use of communication can have a positive effect in respect of the social diversification hypothesis of Mesch (2007) since it allows the creation of networks and contacts that can be very useful for minors and that can help them to progress socially. Nevertheless, the opportunity for social progress may be curtailed by the subsequent reduction in the use of computers and tablets; devices that are most closely linked to creativity and information. These difficulties point more to the perpetuation of inequality than to a possible egalitarian effect. In this sense, it seems important to have public policies that provide immigrant homes with equipment and connections to the Internet.

The absence of digital skills and computer devices in the home hinders young people when performing some school tasks. As they rise through the school structure, there is an increasing number of activities that require digital equipment and skills. A deficit in this area will hold them back, perpetuating the situation of inequal- 
ity and exclusion. Immigrant children connect to the Internet from their homes less often than their Spanish peers; connection from the school and other support centres helps to reduce that gap. As with previous studies (Cabello, 2013; Simões et al., 2013), this study shows the importance of initiatives providing Internet access to underprivileged children, to allow them to acquire the necessary skills and follow their academic career.

Because of their particular circumstances, immigrant children are especially vulnerable to online risks. Given the important role played by parental mediation in preventing and managing Internet risks and improper usage, specific actions are required where such mediation is lacking. As Paus-Hasebrink et al. (2014) mention at a European level, nearly all children from socially disadvantaged groups have a limited knowledge of online risks and tend not to weigh up the information they receive from the media. At the same time, their parents are not always capable of explaining the origin of such risks. Our study confirms this conclusion. It also shows that while general education regarding ICT and bullying has increased, contact with strangers and other problematic situations is still important for all children and is particularly essential for these groups. Deficits in this area were detected among nearly all the immigrant groups studied. In most cases, the children mentioned either very restrictive mediation strategies by their parents or, conversely, the absence of such measures, normally as a result of their parents' lack of digital literacy. Where family intervention is lacking, schools and child support centres must attend to this issue.

Digital tools for socialisation can be useful in facilitating integration: Whatsapp and Instagram - to mention only the most widely used platforms-allow them to interact with family and friends as well as fashion and cultural influencers, just as their Spanish peers do. In particular, the democratisation of Internet access and the simplicity of smartphone use has facilitated contact between immigrant children and their home countries. Although physically removed from their immediate or extended families, the technology allows them to retain their cultural heritage and social capital which helps cultivate a sense of transnational belonging in accordance with their preferences, which can combat their sense of rootlessness.

Among children who might otherwise risk remaining bound to very insular communities, technology allows them to access new ideas, interests and hobbies, opening up new possibilities for future employment and personal development. Access to such opportunities is unquestionably positive. The risks mentioned by immigrant children do not essentially differ from those of their native peers (Smahel \& Wright, 2014), the main difference being the existence of easily accessible xenophobic online content which might be classed as hate speech. As well as preventing the development of healthy coexistence, such content has a negative effect on immigrant children by perpetuating stereotypes and victimisation, further hindering integration and preventing them from overcoming pre-assigned limitations.

\section{Acknowledgements}

This research for this article has been funded by the Department of Education of the Basque Government and by the Spanish Ministry of Economy and Innovation.

\section{Conflict of Interests}

The authors declare no conflict of interests.

\section{References}

Abbas, T. (2008). Educating Muslims: Current national and international debates. British Journal of Sociology of Education, 29(2), 243-245.

Bindé, J. (2005). Towards knowledge societies: UNESCO world report. Paris: UNESCO Publishing.

Borjas, G. J. (1985). Assimilation, changes in cohort quality, and the earnings of immigrants. Journal of Labour Economics, 3(4), 463-489.

Buckingham, D., \& de Block, L. (2005). Children in communication about migration (Final report). Brussels: European Commission, Directorate-General for Research.

Cabello, P. (2013). A qualitative approach to the use of ICTs and its risks among socially disadvantaged early adolescents and adolescents in Madrid, Spain. Communications, 38(1), 61-83.

Calero, J., \& Escardíbul, J. O. (2016). Proceso educativo y resultados del alumnado nativo y de origen inmigrante en España. Un análisis basado en PISA-2012 [Educational process and results of the native student and of immigrant origin in Spain. An analysis based on PIS-2012]. Estudios de Economía Aplicada, 34(2), 413-438.

Cea D’Ancona, M. A. (2016). Percepción social de las migraciones en España [Social perception of migrations in Spain]. Panorama Social, 24, 129-144.

Clark, K. (2005). Serving underserved communities with instructional technologies: Giving them what they need, not what you want. Urban Education, 40(4), 430-445.

D’Haenens, L., \& Ogan, C. (2013). Internet-using children and digital inequality: A comparison between majority and minority Europeans. Communications, 38(1), 41-60.

De Leeuw, S., \& Rydin, I. (2007). Migrant children's digital stories: Identity formation and self-representation through media production. European Journal of Cultural Studies, 10(4), 447-464.

DiMaggio, P., \& Hargittai, E. (2001). From the 'digital divide' to 'digital inequality': Studying Internet use as penetration increase (Working Paper 19). Princeton, NJ: Center for Arts and Cultural Policy Studies, Princeton University. Retrieved from www.princeton.edu/ 
artspol/workpap/WP15\%20-\%20DiMaggio+Hargit tai.pdf20DiMaggio\%2BHargittai.pdf

Domingo, A., \& Sabater, A. (2013). Crisis económica y emigración: La perspectiva demográfica [Economic crisis and emigration: The demographic perspective]. In E Aja, J Arango, \& J Oliver (Ed.), Inmigración y crisis: Entre la continuidad y el cambio. Anuario de Inmigración en España (pp. 60-87). Barcelona: Centro de Estudios y Documentación Internacionales de Barcelona.

Drotner, K., \& Kobbernagel, C. (2014). Toppling hierarchies? Media and information literacies, ethnicity, and performative media practices. Learning, Media \& Technology, 39(3), 409-428. https://doi.org/ 10.1080/17439884.2014.964255

Foessa, F. (2014). Análisis y perspectivas 2014: Precariedad y cohesión social [Analysis and perspectives 2014: Precariousness and social cohesion]. Madrid: Cáritas Española.

Garmendia, M., Garitaonandia, C., Martínez, G., \& Casado, M. A. (2012). The effectiveness of parental mediation. In S. Livingstone, L. Haddon, \& A. Gorzig (Eds.), Children, risk and safety on the internet: Research and policy challenges in comparative perspective (pp. 231-244). Bristol: Policy Press.

Garmendia, M., Jiménez, E., Casado, M. A., Garitaonandia, C., \& Mascheroni, G. (2017). Net children go mobile: Risks and opportunities on internet and the use of mobile devices amongst Spanish children (2010-2015). Madrid: Red.es, Universidad del País Vasco and Euskal Herriko Unibertsitatea.

Godenau, D., Rinken, S., Martínez de Lizarrondo, A., \& Moreno, G. (2014). La integración de los inmigrantes en España: Una propuesta de medición a escala regional [The integration of immigrants in Spain: A proposal for measurement at a regional scale]. Madrid: Ministerio de Empleo y Seguridad Social.

Goggin, G. (2010). Global mobile media. New York, NY: Routledge.

Goggin, G., \& Hjorth, L. (2014). The Routledge companion to mobile media. New York, NY: Routledge.

Gui, M. (2007). Formal and substantial Internet information skills: The role of socio-demographic differences on the possession of different components of digital literacy. First Monday, 12(9). Retrieved from firstmonday.org/ojs/index.php/fm/article/view/2009 $/ 1884$

Hardaker, G., Sabki, A. A., \& Iqbal, J. (2017). Perceptions of inequalities in access and usage of ICT in Islamic faith schools. International Journal of Inclusive Education, 21(9), 881-893.

Hjorth, L., \& Goggin, G. (2009). Mobile technologies: From telecommunications to media. London: Routledge.

Huertas, A., Martínez, Y., \& Moreras, J. (2013). Prácticas y consumos mediático-culturales del colectivo marroquí en España [Practices and media-cultural consumption of the Moroccan collective in Spain].
Madrid: Fundación Alternativas.

Ikuspegi. (2017). Barómetro 2016. Percepciones y actitudes hacia la población de origen extranjero [Barometer 2016. Perceptions and attitudes towards the population of foreign origin]. Bilbao: Universidad del País Vasco.

INE. (2016). Cifras de población y censos demográficos [Population figures and demographic census]. Retrieved from https://www.ine.es/dyngs/INEbase/es/ categoria.htm?c=Estadistica_P\&cid=1254735572981

INE. (2017). Instituto Nacional de Estadística [National Statistics Institute]. Spanish Statistical Office. Retrieved from www.ine.es

IOÉ. (2012). Impacto de la crisis sobre la población inmigrante [Impact of the crisis on the immigrant population]. Madrid: International Organization for Migration.

IOÉ. (2013). La población inmigrada hacia la crisis: ¿̇mirando hacia otro lado? [The immigrant population towards the crisis: looking the other way?]. Retrieved from https://www.colectivoioe.org/uploads/ 0e22cdc4cf3eebeac22b81ad7ac32062f9cf9cf4.pdf

Izquierdo, A. (2011). Del sueldo al arraigo: La tarea de la política inmigratoria tras la crisis (From the salary to the roots: The task of immigration policy after the crisis In E Aja, J Arango \& J Oliver (Ed.). Inmigración y crisis económica. Impactos actuales y perspectivas de futuro. Anuario de la inmigración en España. 2010. Centro de Estudios y Documentación Internacionales de Barcelona, Barcelona, 262-275.

Jackson, L. A., Eye, A. V., \& Biocca, F. A. (2003). Does home Internet use influence the academic performance of low-income children? Findings from the Homenettoo project. Paper presented at the First Latin American Web Congress.

Katz, V. S., Gonzalez, C., \& Clark, K. (2017). Digital inequality and developmental trajectories of low-income, immigrant, and minority children. Pediatrics, 140(2), S132-S136.

Khan, F., \& Ghadially, R. (2010). Empowerment through ICT education, access and use: A gender analysis of Muslim youth in India. Journal of International Development, 22(5), 659-673.

Lara, L. (2014). Psychological well-being of immigrants in Spain: The immigrant paradox. Procedia: Social and Behavioral Sciences, 132, 544-548.

Leurs, K., \& Ponzanesi, S. (2013). Bits of homeland: Generational and gender transformations of Moroccan-Dutch youth using digital technologies. Observatorio, 89-110. http://dx.doi.org/10.15847/ obsOBS002013666

Livingstone, S. \& Helsper, E. (2010). Balancing opportunities and risks in teenagers' use of the internet: the role of online skills and internet self-efficacy. New Media and Society, 12(2), 309-329.

Livingstone, S., Haddon, L., Görzig, A., \& Ólafsson, K. (2011). Risks and safety on the internet: The perspective of European children. Full findings. London: LSE, 
EU Kids Online.

Lobera, J., Arco, V., \& Giménez, C. (2017). Toward a multi-ethnic public sphere? Media consumption in highly diverse districts in Spain. International Migration, 55(2), 39-52.

Mahía, R., \& de Arce, R. (2014). Pobreza de la población extranjera en España [Poverty of the foreign population in Spain]. In J. Arango, D. Moya, \& J. Oliver (Eds.), Inmigración y emigración: Mitos y realidades. Anuario de la inmigración en España 2013 (pp. 138-162). Barcelona: CIDOB.

Martínez de Lizarrondo, A. (2016). Naturalizaciones en España: Indicador de integración y estrategia frente a la crisis [Naturalizations in Spain: Indicator of integration and strategy in the face of the crisis]. Migraciones, 39, 9-43.

Mascheroni, G., \& Ólafsson, K. (2014). Net children go mobile: Risks and opportunities (2nd ed.). Milano: Educatt.

Massey, D. S., \& Eggers, M. L. (1990). The ecology of inequality: Minorities and the concentration of poverty, 1970-1980. American Journal of Sociology, 95(5), 1153-1188.

Mesch, Gustavo S. \& Talmud, I. (2007). Similarity and the quality of online and offline social relationships among adolescents in Israel. Journal of Research on Adolescence, 17(2), 455-465.

Mesch, G. S. (2012). Minority status and the use of computer-mediated communication: A test of the social diversification hypothesis. Communication Research, 39(3), 317-337.

Mullor, M. (2011). Inmigrantes subsaharianos. Una aproximación a las claves de la exclusión [SubSaharan immigrants. An aproximation of the keys of the exclusion]. Cuadernos de la EPIC, 84. Madrid: Escuela de Profesionales de Inmigración y Cooperación (EPIC) de la Comunidad de Madrid.

Norris, P. (2001). Digital divide: Civic engagement, information poverty, and the Internet worldwide. Cambridge, MA: Cambridge University Press.

Paus-Hasebrink, I., Ponte, C., Dürager, A., \& Bauwens, J. (2012). Understanding digital inequality: The interplay between parental socialisation and children's development. In S. Livingstone, L. Haddon, \& A. Gorzig (Eds.), Children, risk and safety on the internet: Research and policy challenges in comparative perspective (pp. 257-271). Bristol: Policy Press.

Paus-Hasebrink, I., Sinner, P., \& Prochazka, F. (2014). Children's online experiences in socially disadvantaged families: European evidence and policy recommendations. London: LSE, EU Kids Online.

Peter, J., \& Valkenburg, P. M. (2006). Adolescents' inter- net use: Testing the "disappearing digital divide" versus the "emerging digital differentiation" approach. Poetics, 34(4/5), 293-305.

Portes, A. (Ed.). (1995). The economic sociology of immigration. New York, NY: Russell Sage Foundation.

Rinken, S. (2015). Actitudes hacia la inmigración y los inmigrantes. ¿En qué es España excepcional? [Attitudes toward immigration and immigrants. What is Spain exceptional?]. Migraciones, 37, 53-74.

Robinson, L. (2009). A taste for the necessary. Information, Communication \& Society, 12(4), 488-507.

Salemink, K. (2016). Digital margins: Social and digital exclusion of Gypsy-travellers in the Netherlands. Environment and Planning, 48(6), 1170-1187.

Simões, J. A., Ponte, C., \& Jorge, A. (2013). Online experiences of socially disadvantaged children and young people in Portugal. Communications: The European Journal of Communication Research, 38(1), 85-106.

Smahel, D., \& Wright, M. (2014). The meaning of online problematic situations for children: Results of crosscultural qualitative investigation in nine European countries. London: LSE, EU Kids Online.

Strohmeier, D., Kärnä, A., \& Salmivalli, C. (2011). Intrapersonal and interpersonal risk factors for peer victimization in immigrant youth in Finland. Developmental Psychology, 47(1), 248-258.

Third, A., Bellerose, D., Dawkins, U., Keltie, E., \& Pihl, K. (2014). Children's rights in the digital age: A download from children around the world. Melbourne: Young and Well Cooperative Research Centre.

TIC Kids Online Brasil. (2017). ICT kids online Brazil: Survey on Internet use by children in Brazil 2016. São Paulo: Brazilian Internet Steering Committee (CGI).

Unicef. (2017). Children affected by migration. Retrieved from http://www.unicef.cn/en/child-protection/ children-affected-by-migration

Van Dijk, J. (2005). The deepening divide. Inequality in the information society. Thousand Oaks, CA: Sage Publications.

Venkataswamya, S., \& Vidyapeetham, A. (2015). Digital access and inequality among primary school children in rural Coimbatore. Media Watch, 6(1), 103-123.

Wang, P.-Y. (2013). Examining the digital divide between rural and urban schools: Technology availability, teachers' integration level and students' perception. Journal of Curriculum and Teaching, 2(2), 127-139.

Yang, Y., Hu, X., Qu, Q., Lai, F., Shi, Y., Boswell, M., \& Rozelle, S. (2013). Roots of tomorrow's digital divide: Documenting computer use and internet access in China's elementary schools today. China \& World Economy, 21(3), 61-79. 


\section{About the Authors}

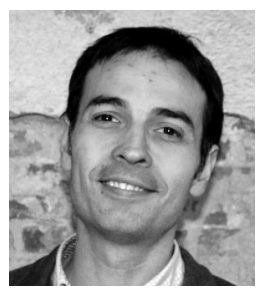

Miguel Ángel Casado is an Assistant Professor at the Department of Audiovisual Communication and Advertising (University of the Basque Country, Spain) where he teaches the course Internet and the Cultural Industries, as well as Tools for Qualitative Research. His research interests include the economics of the cultural industry, public media systems, and children and new media. He has been a member of the European research network EU KIDS ONLINE and now is involved in different research projects funded by the Spanish Ministry of Innovation.

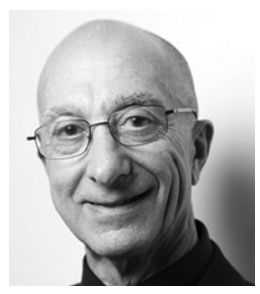

Carmelo Garitaonandia is a Professor of Journalism at the University of the Basque Country, PhD in Political Sciences, BA in Law and Master of Audiovisual Communication. He has written numerous scientific articles and books on topics related to the history of communication, regional TV, digital TV and digital technologies and their influence on children and teenagers. He is a member of the EU Kids Online network.

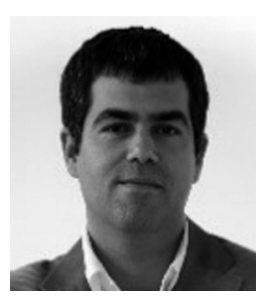

Gorka Moreno is a Professor of Sociology at the University of the Basque Country. He has a PhD in Sociology. He is the director of Ikuspegi-The Basque Immigration Observatory. He has written many scientific articles and books on topics related to the welfare state, social exclusion and poverty, attitudes toward migrants and international migrations. He is a member of the Partehartuz research group whose objective is to develop public participation in social and political policies.

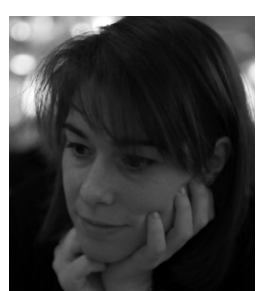

Estefanía Jiménez is an Assistant Professor at the University of the Basque Country. She has been a visiting fellow at UAB (Barcelona), ITESM (Mexico) and the University of Oxford, and has been a member of EU Kids Online since 2012. She has published articles related to media, digital technologies and their relationship with children and teenagers both in journals and in general-interest media. She collaborates with institutions related to children's rights and cyber-security and is also a regular contributor to the media. 